\title{
ANALISIS STRUKTUR MODAL PADA PT. MUSTIKA RATU TBK DI BURSA EFEK INDONESIA PERIODE 2010-2015
}

\author{
Oleh : \\ *) Wella Sandria, S.E., M.Sc. \\ **) Dosen Tetap STIE Muhammadiyah Jambi
}

\begin{abstract}
Abstrak
Penelitian ini berjudul "Analisis Struktur Modal Pada PT Mustika Ratu Tbk Di Bursa Efek Indonesia Periode 2010-2015“, dengan objek penelitian PT. Mustika Ratu Tbk.

Tujuan penelitian ini adalah untuk mengetahui gambaran perkembangan dan perubahan struktur modal pada PT. Mustika Ratu Tbk dari tahun 2010-2015 serta untuk mengetahui apakah struktur modal yang telah diterapkan dapat meminimumkan biaya modal pada PT. Mustika Ratu Tbk dari tahun 2010-2015.

Metode analisis yang digunakan adalah metode analisis kuantitatif. Alat analisis yang digunakan adalah rumus yang berkaitan dengan struktur modal yaitu rumus rasio leverage, struktur modal dan biaya modal rata-rata tertimbang (WACC).

Dari hasil analisis menunjukkan bahwa dalam menetapkan struktur modal pada tahun 2010-2015 lebih banyak menggunakan modal sendiri. Perkembangan modal sendiri perusahaan mengalami peningkatan. Sementara perkembangan hutang jangka panjang mengalami fluktuasi. Akibat penggunaan modal sendiri tersebut biaya modal rata - rata tertimbang PT Mustika Ratu Tbk yaitu : pada tahun 2010 WACC sebesar 8,65\%, pada tahun 2011 sebesar 12,65\%, pada tahun 2012 sebesar 14,43\%, pada tahun 2013 sebesar 3,69\%, pada tahun 2014 sebesar 5,36\%, dan pada tahun 2015 sebesar 1,42\%. Jadi struktur modal yang optimum terjadi pada tahun 2015 karena biaya modalnya merupakan biaya modal terendah.
\end{abstract}

Kata Kunci : Struktur Modal, Rasio Leverage, WACC.

\section{Pendahuluan}

Pengelolaan fungsi keuangan yang disebut manajemen keuangan merupakan salah satu fungsi operasional perusahaan. Ada tiga keputusan utama dalam manajemen keuangan pada suatu perusahaan yaitu keputusan pendanaan, keputusan investasi, dan kebijakan dividen. Manajemen keuangan dapat diartikan sebagai manajemen dana, baik yang berkaitan dengan pengalokasian dana dalam berbagai bentuk investasi secara efektif maupun usaha pengumpulan dana untuk pembiayaan investasi atau pembelanjaan secara efektif dan efesien.

Struktur modal adalah pembelanjaan permanen dimana mencerminkan perimbangan antara hutang jangka panjang dengan modal sendiri (Riyanto:2001). Menurut Suad Husnan dan Pudjiastuti (2006), semua struktur modal adalah baik, tetapi kalau dengan mengubah struktur modal ternyata nilai perusahaan berubah maka akan diperoleh struktur modal terbaik. Perusahaan perlu mencapai struktur modal yang optimal sehingga biaya modal perusahaan 
dapat diminimalisir atau perusahaan dapat memaksimalkan nilai perusahaan. Agus Sartono (2011) menyatakan bahwa struktur modal yang optimal adalah struktur modal yang dapat meminimalkan biaya modal rata - rata atau memaksimalkan nilai perusahaan.

Struktur modal merupakan masalah penting dalam pengambilan keputusan mengenai pendanaan perusahaan (Brigham dan Houston:2001). Apabila nilai struktur modal berada diatas atau lebih besar dari satu, maka berarti perusahaan memiliki jumlah hutang yang lebih besar daripada jumlah modal sendiri. Kondisi ini tidak sesuai dengan teori struktur modal yang optimal, dimana seharusnya jumlah hutang perusahaan tidak boleh lebih besar daripada modal sendiri. Sementara itu kebanyakan investor lebih tertarik menanamkan modalnya kedalam bentuk investasi pada perusahaan yang mempunyai struktur modal tertentu yang besarnya kurang dari satu. Karena jika struktur modal lebih besar dari satu berarti risiko yang ditanggung oleh investor menjadi meningkat.

PT. Mustika Ratu Tbk merupakan salah satu perusahaan domestik yang bergerak dibidang kosmetik. Perusahaan ini adalah salah satu perusahaan yang terdaftar di Bursa Efek Indonesia.

Perkembangan hutang jangka panjang pada PT Mustika Ratu Tbk mengalami fluktuasi dan perkembangan modal sendiri pada PT Mustika Ratu mengalami fluktuasi. Berdasarkan kenyataan diatas, maka dapat dikatakan bahwa struktur modal pada PT Mustika Ratu Tbk dari tahun 2010 sampai dengan 2015lebih banyak menggunakan modal sendiri dalam menjalankan aktivitasnya dibandingkan dengan menggunakan hutang. Untuk menjalankan kegiatan perusahaan, maka diperlukan pembelanjaan yang baik agar dapat mengkombinasikan berbagai sumber modal yang tersedia dengan biaya semurah mungkin, karena masing-masing sumber modal tersebut memiliki biaya modal yang berbeda-beda. Atas dasar permasalahan di atas maka tujuan dari penelitian ini adalah (1) Untuk mengetahui gambaran perkembangan dan perubahan struktur modal pada PT Mustika Ratu Tbk dari tahun 2010-2015. (2) Untuk mengetahui apakah struktur modal yang telah diterapkan dapat meminimumkan biaya modal pada PT Mustika Ratu Tbk dari tahun 2010-2015.

\section{Tinjauan Pustaka}

Menurut Riyanto (2001) modal adalah barang-barang yang ada dirumah tangga perusahaan dalam fungsi produktivitas untuk membentuk pendapatan. Menurut Suad Husnan (2006) modal adalah hak atau bagian yang dimiliki oleh perusahaan yang diajukan dalam pos 
modal (modal saham), surplus dan laba yang ditahan, atau kelebihan nilai aktiva yang dimiliki oleh perusahaan terhadap seluruh hutang-hutangnya. Dapat disimpulkan bahwa modal adalah bagian dari perusahaan untuk menjalankan aktivitas operasional perusahaan untuk mendapatkan laba.

\section{Struktur Modal}

Menurut Riyanto (2001) struktur modal adalah pembelanjaan permanen dimana mencerminkan perimbangan antara hutang jangka panjang dengan modal sendiri. Menurut Suad Husnan (2004) struktur modal adalah perimbangan atau perbandingan antara modal asing dengan modal sendiri. Dapat disimpulkan bahwa struktur modal adalah perimbangan atau perbandingan antara hutang jangka panjang dengan modal sendiri.

Struktur modal suatu perusahaan, secara umum terdiri atas beberapa komponen yaitu :

1. Hutang Jangka Panjang

Menurut Riyanto (2001) hutang jangka panjang adalah hutang yang waktunya adalah panjang, umumnya lebih dari 10 tahun atau hutang yang jatuh tempo pembayarannya panjang.

\section{Modal Sendiri}

Menurut Munawir (2010) modal sendiri adalah hak atau bagian yang dimiliki oleh perusahaan yang ditunjukkan dalam pos modal (modal saham), surplus dan laba yang ditahan, atau kelebihan nilai aktiva yang dimiliki oleh perusahaan terhadap seluruh hutang - hutangnya.

Penetapan struktur modal dalam suatu perusahaan dipengaruhi oleh beberapa faktor (Riyanto:2001) antara lain :

1. Tingkat Bunga

2. Stabilitas dari "Earning"

3. Susunan Dari Aktiva

4. Kadar Resiko dari Aktiva

5. Besarnya Jumlah Modal Yang Dibutuhkan

6. Keadaan Pasar Modal

7. Sifat Manajemen

8. Besarnya Suatu Perusahaan 


\section{Metode Penelitian}

Metode penelitian yang digunakan adalah analisis kuantitatif yang dilakukan dengan cara membandingkan laporan keuangan dengan data lainnya dari tahun ke tahun, serta menghitung perubahan yang terjadi.

\section{Metode Analisis}

Untuk menjawab tujuan penelitian digunakan tahapan analisis data sebagai berikut :

a. Analisis Trend Horizontal, yaitu suatu metode atau teknik analisa untuk mengetahui perubahan struktur modal dengan membandingkan masing-masing komponen dalam struktur modal antara tahun tertentu dengan tahun sebelumnya dalam persentase, Lukman Syamsudin (2009) rumus trend horizontal adalah :

Dimana :

$$
P \quad=\frac{T-T}{T} \times 100
$$

$\mathrm{Ta}=$ tahun yang dianalisis

Td $=$ tahun dasar

Rasio Leverage, digunakan untuk mengukur tingkat sejauh mana aktiva perusahaan yang telah dibiayai oleh hutang (Syamsudin:2009)

1) Debt Ratio

Yaitu pengukuran jumlah aktiva perusahaan yang dibiayai oleh hutang atau modal yang berasal dari kreditur.

$$
\text { Debt Ratio }=\frac{\text { Total Hutang }}{\text { Total Aktiva }}
$$

\section{2) The Debt Equity Ratio}

Yaitu perbandingan antara hutang jangka panjang dengan modal sendiri perusahaan.

$$
\text { The Debt Equity Ratio }=\frac{\text { Hutang Jangka Panjang }}{\text { Modal Sendiri }}
$$

\section{3) The Debt To Total Capitalization}

Yaitu mengukur berapa besar modal jangka panjang perusahaan yang dibiayai oleh kreditur.

$$
\text { The Debt Equity Ratio }=\frac{\text { Hutang Jangka Panjang }}{\text { hutang jangka panjang }+ \text { Modal }}
$$


Biaya Modal, yaitu menghitung biaya modal pada komposisi struktur modal perusahaan, yaitu :

1) Biaya Hutang (Cost of Debt), biaya yang harus dibayar perusahaan untuk mendapatkan modal yang berasal dari hutang jangka panjang.

Dimana :

$$
\mathrm{Ki}=\frac{\mathrm{b}}{\mathrm{Io}}(1-\mathrm{t})
$$

$$
\begin{array}{ll}
\mathrm{b} & =\text { biaya bunga hutang } \\
\mathrm{I} & =\text { jumlah hutang } \\
\mathrm{t} & =\text { pajak }
\end{array}
$$

2) Biaya Laba Ditahan, biaya yang harus dikeluarkan perusahaan untuk mendapatkan modal yang berasal dari saham biasa, dimana biaya modal ini sebesar tingkat keuntungan yang diisyaratkan oleh investor saham biasa.

$$
\begin{gathered}
\mathrm{Kr}=\mathrm{Ke} \\
\mathrm{Kr}=\frac{\mathrm{Di}}{\mathrm{P}} \times 100 \%
\end{gathered}
$$

Dimana :

$\mathrm{Kr} \quad$ = biaya laba ditahan

$\mathrm{Ke} \quad=$ biaya modal saham

Di = deviden per lembar saham

$\mathrm{P} \quad=$ harga saham

3) Biaya Modal Saham, biaya yang harus dikeluarkan perusahaan untuk mendapatkan modal yang berasal dari saham biasa, dimana biaya modal ini sebesar tingkat keuntungan yang diisyaratkan oleh investor saham biasa (Sutrisno, 2009).

$$
\mathrm{Ke}=\frac{\text { deviden persaham }}{\text { harga saham }} \times 100 \%
$$

4) Biaya Modal Rata-rata Tertimbang (Weight Average Cost of Capital/WACC), biaya atas seluruh modal yang digunakan perusahaan yang merupakan perhitungan biaya atas modal hutang dan modal sendiri setelah diperhitungkan pajak. (Riyanto, 2001).

Dimana :

$$
\mathrm{WACC}=\% \mathrm{D}(\mathrm{Ki})+\% \mathrm{CS}(\mathrm{Ke})+\mathrm{Re}(\mathrm{Kre})
$$

$$
\begin{aligned}
& \text { WACC = biaya modal rata-rata tertimbang } \\
& \mathrm{Ki} \quad=\text { biaya hutang } \\
& \mathrm{Ke} \quad=\text { biaya modal saham } \\
& \text { Kre } \quad \text { biaya laba ditahan }
\end{aligned}
$$




$\begin{array}{ll}\% \mathrm{D} & =\text { persentase dari hutang didalam struktur modal } \\ \% \mathrm{CS} & =\text { persentase dari saham didalam struktur modal } \\ \% \mathrm{Re} & =\text { persentase laba ditahan didalam struktur modal }\end{array}$

\section{HASIL DAN PEMBAHASAN}

\section{Rasio Leverage PT Mustika Ratu Tbk}

Rasio leverage merupakan rasio keuangan yang digunakan untuk mengukur kemampuan perusahaan dalam memenuhi kewajiban baik jangka pendek maupun jangka panjang.

Tabel 1

Perkembangan Rasio Leverage PT. Mustika Ratu Tbk Tahun $2010-2015$

\begin{tabular}{|c|c|c|c|}
\hline Rasio Leverage & Tahun & Rasio (\%) & Perubahan $(\%)$ \\
\hline \multirow{6}{*}{ Debt Ratio (\%) } & 2010 & 12,64 & - \\
\hline & 2011 & 15,16 & 19,98 \\
\hline & 2012 & 15,28 & 0,75 \\
\hline & 2013 & 14,06 & $(7,99)$ \\
\hline & 2014 & 23,02 & 63,79 \\
\hline & 2015 & 24,15 & 4,90 \\
\hline \multirow{6}{*}{$\begin{array}{c}\text { Debt Equity } \\
\text { Ratio } \\
(\%)\end{array}$} & 2010 & 4,29 & - \\
\hline & 2011 & 4,47 & 4,18 \\
\hline & 2012 & 3,78 & $(15,45)$ \\
\hline & 2013 & 3,66 & $(3,12)$ \\
\hline & 2014 & 6,04 & 65,01 \\
\hline & 2015 & 6,11 & 1,21 \\
\hline \multirow{6}{*}{$\begin{array}{l}\text { Debt to Total } \\
\text { Capitalization } \\
\text { (\%) }\end{array}$} & 2010 & 4,11 & - \\
\hline & 2011 & 4,28 & 4,00 \\
\hline & 2012 & 3,64 & $(14,89)$ \\
\hline & 2013 & 3,53 & $(3,01)$ \\
\hline & 2014 & 5,69 & 61,30 \\
\hline & 2015 & 5,76 & 1,14 \\
\hline
\end{tabular}

Berdasarkan tabel 1 diatas, menunjukkan bahwa rasio leverage perusahaan dari tahun 2010-2015 mengalami fluktuasi. Berfluktuasinya rasio leverage tersebut disebabkan karena hutang jangka panjang yang dimiliki oleh perusahaan juga mengalami fluktuasi.

Debt Ratio perusahaan pada tahun 2010-2011 meningkat sebesar 19,98\%, pada tahun 2011-2012 meningkat sebesar 0,75\%, pada tahun 2012-2013 menurun sebesar 7,99\%, pada tahun 2013-2014 meningkat sebesar 63,79\%, dan pada tahun 2014-2015 
meningkat sebesar 4,90\%. debt ratio perusahaan hanya mengalami penurunan pada tahun 2012-2013, dan pada tahun-tahun berikutnya debt ratio mengalami kenaikan, ini menunjukkan bahwa resiko keuangan yang dihadapi oleh perusahaan semakin tinggi karena hutang tersebut mempunyai beban bunga yang tetap yang harus ditanggung oleh perusahaan.

Berdasarkan tabel 1 diatas, menunjukkan bahwa debt equity ratio mengalami fluktuasi, dimana pada tahun 2010-2011 meningkat sebesar 4,18\%, pada tahun 20112012 menurun sebesar 15,45\%, pada tahun 2012-2013 menurun kembali sebesar 3,12\%, pada tahun 2013-2014 mengalami peningkatan sebesar $65,01 \%$, dan pada tahun 2014-2015 meningkat sebesar 1,21\%. Penurunan debt equity ratio hanya terjadi pada tahun 2012 dan 2013 saja, dan pada tahun berikutnya mengalami peningkatan ini menunjukkan bahwa dalam struktur modal tersebut resiko keuangan yang ditanggung oleh perusahaan semakin tinggi karena debt equity ratio menunjukkan seberapa besar hutang jangka panjang yang dapat dijamin dengan modal sendiri.

Berdasarkan tabel 1 diatas menunjukkan bahwa debt to total capitalization perusahaan berfluktuasi. Pada tahun 2010-2011 meningkat sebesar 4,00\%, pada tahun 2011-2012 menurun sebesar 14,89\%, pada tahun 2012-2013 menurun kembali sebesar 3,01\%, pada tahun 2013-2014 meningkat sebesar 61,30\%, dan pada tahun 2014-2015 meningkat sebesar 1,14\%. Nilai debt to total capitalization pada tahun 2010, 2011, 2012, 2013, 2014, 2015 berturut turut adalah 4,11\%, 4,28\%, 3,64\%, 3,53\%, 5,69\%, $5,76 \%$. Nilai debt to total capitalization pada tiap tahunnya menunjukkan bahwa dari keseluruhan modal jangka panjang yang terdapat di dalam modal jangka panjang adalah merupakan pinjaman jangka panjang perusahaan.

\section{Analisis Struktur Modal PT. Mustika Ratu Tbk}

Analisis struktur modal pada dasarnya digunakan untuk mengetahui perbandingan pendanaan jangka panjang perusahaan yang ditunjukkan oleh perbandingan hutang jangka panjang terhadap modal sendiri. Analisis struktur modal juga digunakan untuk mengetahui komposisi pendanaan yang digunakan oleh PT Mustika Ratu Tbk serta kebijaksanaan manajemen dalam menetapkan struktur modalnya. Komposisi struktur modal pada PT Mustika Ratu Tbk seperti terlihat pada tabel berikut 
Tabel 2

Struktur Modal PT Mustika Ratu Tbk

Tahun $2010-2015$

\begin{tabular}{|c|c|c|c|}
\hline \multirow[b]{2}{*}{ Tahun } & \multirow[b]{2}{*}{ Struktur Modal } & \multicolumn{2}{|c|}{ Komposisi } \\
\hline & & Dalam Rupiah & Dalam (\%) \\
\hline \multirow{3}{*}{2010} & Hutang Jangka Panjang & 10.638.267.816 & 4,11 \\
\hline & Modal Sendiri & 248.064 .449 .550 & 95,89 \\
\hline & Total & 258.702.717.366 & 100 \\
\hline \multirow{3}{*}{2011} & Hutang Jangka Panjang & 12.000 .508 .887 & 4,28 \\
\hline & Modal Sendiri & 268.606.924.389 & 95,72 \\
\hline & Total & 280.607.433.276 & 100 \\
\hline \multirow{3}{*}{2012} & Hutang Jangka Panjang & 10.939.737.916 & 3,64 \\
\hline & Modal Sendiri & 289.604 .590 .185 & 96,36 \\
\hline & Total & 300.544.328.101 & 100 \\
\hline \multirow{3}{*}{2013} & Hutang Jangka Panjang & 9.981 .975 .643 & 3,53 \\
\hline & Modal Sendiri & 272.756 .376 .318 & 96,47 \\
\hline & Total & 282.738.351.961 & 100 \\
\hline \multirow{3}{*}{2014} & Hutang Jangka Panjang & 16.916.040.867 & 5,69 \\
\hline & Modal Sendiri & 280.128 .350 .160 & 94,31 \\
\hline & Total & 297.044.391.027 & 100 \\
\hline \multirow{3}{*}{2015} & Hutang Jangka Panjang & 17.165 .678 .527 & 5,76 \\
\hline & Modal Sendiri & 280.857 .007 .040 & 94,24 \\
\hline & Total & 298.022.685.567 & 100 \\
\hline
\end{tabular}

Sumber : www.idx.co.id (diolah dari data)

Berdasarkan analisis struktur modal pada tabel 2 diatas maka dapat diketahui bahwa komposisi struktur modal yang ditetapkan oleh PT Mustika Ratu Tbk dari tahun 2010-2015 sebagian besar menggunakan modal sendiri daripada hutang jangka panjang. Pemilihan pendanaan yang berasal dari modal sendiri oleh PT Mustika Ratu Tbk menunjukkan bahwa manajemen mengurangi resiko finansial yang akan dihadapi oleh PT Mustika Ratu Tbk di masa yang akan datang.

\section{Analisis Biaya Modal (Cost of Capital) PT Mustika Ratu Tbk}

Setiap hutang yang ditarik dari pihak luar untuk membiayai kegiatan perusahaan akan memberikan beban tetap bagi perusahaan, yaitu biaya bunga. Analisis biaya modal ini digunakan untuk menentukan besarnya biaya yang harus dikeluarkan oleh perusahaan sehubungan dengan penggunaan modal dari alternatif sumber pendanaan yang dipilih oleh perusahaan. Perusahaan dalam menentukan struktur modal 
optimal adalah mensyaratkan biaya modal yang minimum. Penetapan biaya atas penggunaan sumber dana secara keseluruhan adalah dengan menggunakan biaya modal rata-rata tertimbang.

Adapun besarnya biaya modal PT Mustika Ratu Tbk dari tahun 2010-2015 dapat dihitung sebagai berikut :

\section{Tahun 2010 :}

Tabel 3

Proporsi dari Struktur Modal PT. Mustika Ratu Tbk yang terdaftar di Bursa Efek Indonesia Tahun 2010

\begin{tabular}{|l|c|c|}
\hline \multirow{2}{*}{\multicolumn{1}{c|}{ Keterangan }} & \multicolumn{2}{c|}{2010} \\
\cline { 2 - 3 } & Jumlah & $\begin{array}{c}\text { Proporsi } \\
(\%)\end{array}$ \\
\hline Hutang Jangka Panjang & 10.638 .267 .816 & 4,11 \\
\hline Modal Saham & 53.500 .000 .000 & 20,68 \\
\hline Laba Ditahan & 194.564 .449 .550 & 75,21 \\
\hline \multicolumn{1}{|c|}{ Jumlah } & 258.702 .717 .366 & 100,00 \\
\hline
\end{tabular}

Sumber : www.idx.co.id (diolah dari data)

$$
\begin{aligned}
& \mathrm{Ki}=\frac{825.988 .342}{10.638 .267 .816}(1-25,92) \\
&= 5,75 \% \\
& \mathrm{Ke}=\frac{57}{650} \times 100 \%=8,77 \%
\end{aligned}
$$

Dari hasil perhitungan tersebut diatas maka biaya modal rata -rata tertimbang atau Weight Average Cost of Capital ( WACC ) PT Mustika Ratu Tbk tahun 2010 dapat dilihat pada tabel berikut :

Tabel 4

Perhitungan WACC pada PT Mustika Ratu Tbk Tahun 2010

\begin{tabular}{|l|c|c|c|}
\hline \multicolumn{1}{|c|}{ Jenis Modal } & $\begin{array}{c}\text { Proporsi } \\
(\%)\end{array}$ & $\begin{array}{c}\text { Biaya } \\
\text { Modal }\end{array}$ & WACC \\
\hline Hutang Jangka Panjang & 4,11 & 5,75 & 0,24 \\
\hline Modal Saham & 20,68 & 8,77 & 1,81 \\
\hline Laba Ditahan & 75,21 & 8,77 & 6,60 \\
\hline \multicolumn{1}{|c|}{ Jumlah } & 100,00 & & 8,65 \\
\hline
\end{tabular}

Sumber : www.idx.co.id (diolah dari data)

Dapat dilihat dari tabel bahwa biaya hutang jangka panjang PT Mustika Ratu pada tahun 2010 adalah sebesar 5,75\%. Biaya modal saham pada tahun 2010 sebesar $8,77 \%$ dan biaya laba ditahan adalah sebesar $8,77 \%$. 
Dari total seluruh biaya tersebut dapatlah dihitung biaya modal rata-rata tertimbang atau biaya modal PT Mustika Ratu Tbk yang terdaftar di Bursa Efek Indonesia pada tahun 2010 adalah sebesar $8,65 \%$.

Tahun 2011 :

Tabel 5

Proporsi dari Struktur Modal PT Mustika Ratu Tbk yang terdaftar di Bursa Efek Indonesia Tahun 2011

\begin{tabular}{|l|c|c|}
\hline \multirow{2}{*}{\multicolumn{1}{|c|}{ Keterangan }} & \multicolumn{2}{c|}{2011} \\
\cline { 2 - 3 } & Jumlah & $\begin{array}{c}\text { Proporsi } \\
(\%)\end{array}$ \\
\hline Hutang Jangka Panjang & 12.000 .508 .887 & 4,28 \\
\hline Modal Saham & 53.500 .000 .000 & 19,07 \\
\hline Laba Ditahan & 215.106 .924 .389 & 76,66 \\
\hline \multicolumn{1}{|c|}{ Jumlah } & 280.607 .433 .276 & 100,00 \\
\hline
\end{tabular}

Sumber : www.idx.co.id (diolah dari data)

$$
\begin{gathered}
\mathrm{Ki}=\frac{775.812 .926}{12.000 .508 .887}(1-24,11)=4,91 \% \\
\mathrm{Ke}=\frac{65}{500} \times 100 \%=13,00 \%
\end{gathered}
$$

Dari hasil perhitungan tersebut diatas maka biaya modal rata-rata tertimbang atau Weight Average Cost of Capital ( WACC ) PT Mustika Ratu Tbk tahun 2011 dapat dilihat pada tabel berikut :

Tabel 6

Perhitungan WACC pada PT Mustika Ratu Tbk Tahun 2011

\begin{tabular}{|l|c|c|c|}
\hline \multicolumn{1}{|c|}{ Jenis Modal } & $\begin{array}{c}\text { Propors } \\
\text { i (\%) }\end{array}$ & $\begin{array}{c}\text { Biaya } \\
\text { Moda } \\
1\end{array}$ & WACC \\
\hline $\begin{array}{l}\text { Hutang Jangka } \\
\text { Panjang }\end{array}$ & 4,28 & 4,91 & 0,21 \\
\hline Modal Saham & 19,07 & 13,00 & 2,48 \\
\hline Laba Ditahan & 76,66 & 13,00 & 9,97 \\
\hline \multicolumn{1}{|c|}{ Jumlah } & 100,00 & & 12,65 \\
\hline
\end{tabular}

Sumber : www.idx.co.id (diolah dari data)

Dapat dilihat dari tabel bahwa biaya hutang jangka panjang PT Mustika Ratu pada tahun 2011 adalah sebesar 4,91\%. Biaya modal saham pada tahun 2011 sebesar $13,00 \%$ dan biaya laba ditahan adalah sebesar $13,00 \%$. 
Dari total seluruh biaya tersebut dapatlah dihitung bahwa biaya modal ratarata tertimbang atau biaya modal PT Mustika Ratu Tbk yang terdaftar di Bursa Efek Indonesia pada tahun 2011 adalah sebesar 12,65\%.

Tahun 2012 :

Tabel 7

Proporsi dari Struktur Modal PT Mustika Ratu Tbk

Yang terdaftar di Bursa Efek Indonesia Tahun 2012

\begin{tabular}{|c|c|c|}
\hline \multirow{2}{*}{ Keterangan } & \multicolumn{2}{|c|}{2012} \\
\hline & Jumlah & Proporsi (\%) \\
\hline $\begin{array}{l}\text { Hutang Jangka } \\
\text { Panjang }\end{array}$ & 10.939.737.916 & 3,64 \\
\hline Modal Saham & 53.500 .000 .000 & 17,80 \\
\hline Laba Ditahan & 236.104 .590 .185 & 78,56 \\
\hline Jumlah & 300.544 .328 .101 & 100,00 \\
\hline
\end{tabular}

Sumber : www.idx.co.id (diolah dari data)

$$
\begin{aligned}
& \mathrm{Ki}=\frac{1 \cdot 125 \cdot 164.969}{10.939 .737 .916}(1-27,73) \\
= & 7,48 \% \\
\mathrm{Ke} & =\frac{72}{490} \times 100 \%=14,69 \%
\end{aligned}
$$

Dari hasil perhitungan tersebut diatas maka biaya modal rata-rata tertimbang atau Weight Average Cost of Capital (WACC) PT Mustika Ratu Tbk tahun 2012 dapat dilihat pada tabel berikut :

Tabel 8

Perhitungan WACC pada PT Mustika Ratu Tbk Tahun 2012

\begin{tabular}{|c|c|c|c|}
\hline \multicolumn{1}{|c|}{ Jenis Modal } & $\begin{array}{c}\text { Proporsi } \\
(\%)\end{array}$ & $\begin{array}{c}\text { Biaya } \\
\text { Modal }\end{array}$ & WACC \\
\hline Hutang Jangka Panjang & 3,64 & 7,43 & 0,27 \\
\hline Modal Saham & 17,80 & 14,69 & 2,61 \\
\hline Laba Ditahan & 78,56 & 14,69 & 11,54 \\
\hline Jumlah & 100,00 & & 14,43 \\
\hline
\end{tabular}

Sumber : www.idx.co.id (diolah dari data)

Dapat dilihat dari tabel bahwa biaya hutang jangka panjang PT Mustika Ratu pada tahun 2012 adalah sebesar 7,43\%. Biaya modal saham pada tahun 2012 sebesar $14,69 \%$ dan biaya laba ditahan adalah sebesar 14,69\%. 
Dari total seluruh biaya tersebut dapat dihitung biaya modal rata-rata tertimbang atau biaya modal PT Mustika Ratu Tbk yang terdaftar di Bursa Efek Indonesia oada tahun 2012 adalah sebesar $14,43 \%$.

Tahun 2013 :

Tabel 9

Proporsi dari Struktur Modal PT Mustika Ratu Tbk

Yang terdaftar di Bursa Efek Indonesia Tahun 2013

\begin{tabular}{|l|c|c|}
\hline \multirow{2}{*}{\multicolumn{1}{c|}{ Keterangan }} & \multicolumn{2}{c|}{2013} \\
\cline { 2 - 3 } & Jumlah & Proporsi (\%) \\
\hline Hutang Jangka Panjang & 9.981 .975 .643 & 3,53 \\
\hline Modal Saham & 53.500 .000 .000 & 18,92 \\
\hline Laba Ditahan & 219.256 .376 .318 & 77,55 \\
\hline \multicolumn{1}{|c|}{ Jumlah } & 282.738 .351 .961 & 100,00 \\
\hline
\end{tabular}

Sumber : www.idx.co.id (diolah dari data)

$$
\begin{gathered}
\mathrm{Ki}=\frac{1.558 .774 .630}{9.981 \cdot 975.643}(1-33,11)=10,45 \% \\
\mathrm{Ke}=\frac{16}{465} \times 100 \%=3,44 \%
\end{gathered}
$$

Dari hasil perhitungan tersebut diatas maka biaya modal rata-rata tertimbang atau Weight Average Cost of Capital (WACC) PT Mustika Ratu Tbk tahun 2013 dapat dilihat pada tabel berikut :

Tabel 10

Perhitungan WACC pada PT Mustika Ratu Tbk Tahun 2013

\begin{tabular}{|l|c|c|c|}
\hline \multicolumn{1}{|c|}{ Jenis Modal } & Proporsi (\%) & Biaya Modal & WACC \\
\hline $\begin{array}{l}\text { Hutang Jangka } \\
\text { Panjang }\end{array}$ & 3,53 & 10,45 & 0,37 \\
\hline Modal Saham & 18,92 & 3,44 & 0,65 \\
\hline Laba Ditahan & 77,55 & 3,44 & 2,67 \\
\hline \multicolumn{1}{|c|}{ Jumlah } & 100,00 & & 3,69 \\
\hline
\end{tabular}

Sumber : www.idx.co.id (diolah dari data)

Dapat dilihat dari tabel bahwa biaya hutang jangka panjang PT Mustika Ratu pada tahun 2013 adalah sebesar 10,45\%. Biaya modal saham pada tahun 2013 sebesar $3,44 \%$ dan biaya laba ditahan adalah sebesar 3,44\%. 
Dari total seluruh biaya tersebut dapat dihitung biaya modal rata-rata tertimbang atau biaya modal PT Mustika Ratu Tbk yang terdaftar di Bursa Efek Indonesia pada tahun 2013 adalah sebesar 3,69\%.

Tahun 2014 :

Tabel 11

Proporsi dari Struktur Modal PT Mustika Ratu Tbk

Yang terdaftar di Bursa Efek Indonesia Tahun 2014

\begin{tabular}{|l|c|c|}
\hline \multirow{2}{*}{ Keterangan } & \multicolumn{2}{c|}{2014} \\
\cline { 2 - 3 } & Jumlah & Proporsi (\%) \\
\hline $\begin{array}{l}\text { Hutang Jangka } \\
\text { Panjang }\end{array}$ & 10.574 .595 .944 & 3,64 \\
\hline Modal Saham & 53.500 .000 .000 & 18,40 \\
\hline Laba Ditahan & 226.628 .350 .160 & 77,96 \\
\hline \multicolumn{1}{|c|}{ Jumlah } & 290.702 .946 .104 & 100,00 \\
\hline
\end{tabular}

Sumber : www.idx.co.id (diolah dari data)

$$
\begin{gathered}
\mathrm{Ki}=\frac{2 \cdot 688 \cdot 038 \cdot 171}{10.574 .595 .944}(1-26,58)=18,66 \% \\
\mathrm{Ke}=\frac{17}{350} \times 100 \%=4,86 \%
\end{gathered}
$$

Dari hasil perhitungan tersebut diatas maka biaya modal rata-rata tertimbang atau Weight Average Cost of Capital (WACC) PT Mustika Ratu Tbk Tahun 2014 dapat dilihat pada tabel berikut :

Tabel 12

Perhitungan WACC pada PT Mustika Ratu Tbk Tahun 2014

\begin{tabular}{|l|c|c|c|}
\hline \multicolumn{1}{|c|}{ Jenis Modal } & $\begin{array}{c}\text { Propors } \\
\text { i (\%) }\end{array}$ & $\begin{array}{c}\text { Biaya } \\
\text { Modal }\end{array}$ & WACC \\
\hline Hutang Jangka Panjang & 3,64 & 18,66 & 0,68 \\
\hline Modal Saham & 18,40 & 4,86 & 0,89 \\
\hline Laba Ditahan & 77,96 & 4,86 & 3,79 \\
\hline \multicolumn{1}{|c|}{ Jumlah } & 100,00 & & 5,36 \\
\hline
\end{tabular}

Sumber : www.idx.co.id (diolah dari data)

Dapat dilihat dari tabel bahwa biaya hutang jangka panjang PT Mustika Ratu pada tahun 2014 adalah sebesar 18,66\%. Biaya modal saham pada tahun 2014 sebesar $4,86 \%$ dan biaya laba ditahan adalah sebesar $4,86 \%$. 
Dari total seluruh biaya tersebut dapat dihitung biaya modal rata - rata tertimbang atau biaya modal PT Mustika Ratu Tbk yang terdaftar di Bursa Efek Indonesia pada tahun 2014 adalah sebesar 5,36\%.

Tahun 2015 :

Tabel 13

Proporsi dari Struktur Modal PT Mustika Ratu Tbk

Yang terdaftar di Bursa Efek Indonesia Tahun 2015

\begin{tabular}{|l|c|c|}
\hline \multirow{2}{*}{\multicolumn{1}{|c|}{ Keterangan }} & \multicolumn{2}{|c|}{2015} \\
\cline { 2 - 3 } & Jumlah & $\begin{array}{c}\text { Proporsi } \\
(\%)\end{array}$ \\
\hline $\begin{array}{l}\text { Hutang Jangka } \\
\text { Panjang }\end{array}$ & 17.165 .678 .527 & 5,76 \\
\hline Modal Saham & 53.500 .000 .000 & 17,95 \\
\hline Laba Ditahan & 227.357 .007 .040 & 76,29 \\
\hline \multicolumn{1}{|c|}{ Jumlah } & 298.022 .685 .567 & 100,00 \\
\hline
\end{tabular}

Sumber : www.idx.co.id (diolah dari data)

$$
\begin{gathered}
\mathrm{Ki}=\frac{3 \cdot 665 \cdot 411 \cdot 293}{17 \cdot 165 \cdot 678 \cdot 527}(1-53,63)=9,90 \% \\
\mathrm{Ke}=\frac{2}{221} \times 100 \%=0,90 \%
\end{gathered}
$$

Dari hasil perhitungan tersebut diatas maka biaya modal rata-rata tertimbang atau Weight Average Cost of Capital (WACC) PT Mustika Ratu Tbk tahun 2015 dapat dilihat pada tabel berikut :

Tabel 14

Perhitungan WACC pada PT Mustika Ratu Tbk tahun 2015

\begin{tabular}{|l|c|c|c|}
\hline \multicolumn{1}{|c|}{ Jenis Modal } & $\begin{array}{c}\text { Proporsi } \\
(\%)\end{array}$ & $\begin{array}{c}\text { Biaya } \\
\text { Modal }\end{array}$ & WACC \\
\hline Hutang Jangka Panjang & 5,76 & 9,90 & 0,57 \\
\hline Modal Saham & 17,95 & 0,90 & 0,16 \\
\hline Laba Ditahan & 76,29 & 0,90 & 0,69 \\
\hline \multicolumn{1}{|c|}{ Jumlah } & 100,00 & & 1,42 \\
\hline
\end{tabular}

Sumber : www.idx.co.id (diolah dari data)

Dapat dilihat dari tabel bahwa biaya hutang jangka panjang PT Mustika Ratu pada tahun 2015 adalah sebesar 9,90\%. Biaya modal saham pada tahun 2015 sebesar $0,90 \%$ dan biaya laba ditahan adalah sebesar $0,90 \%$. 
Dari total seluruh biaya tersebut dapat dihitung biaya modal rata-rata tertimbang atau biaya modal PT Mustika Ratu Tbk yang terdaftar di Bursa Efek Indonesia pada tahun 2015 adalah sebesar 1,42\%.

Struktur modal yang berbeda juga akan dapat menimbulkan perbedaan terhadap biaya modal perusahaan, karena masing-masing sumber modal mempunyai biaya yang berbeda satu sama lainnya. Dari hasil perhitungan, maka dapatlah diketahui biaya modal rata-rata tertimbang perusahaan (Weight Average Cost of Capital) dari tahun 2010-2015 adalah sebagai berikut :

Tabel 15

Weight Average Cost of Capital (WACC)

Pada PT Mustika Ratu Tbk Periode 2010 - 2015

\begin{tabular}{|c|c|}
\hline Tahun & WACC $(\%)$ \\
\hline 2010 & 8,65 \\
\hline 2011 & 12,65 \\
\hline 2012 & 14,43 \\
\hline 2013 & 3,69 \\
\hline 2014 & 5,36 \\
\hline 2015 & 1,42 \\
\hline
\end{tabular}

Sumber : www.idx.co.id (diolah dari data)

Dari data diatas dapat diketahui bahwa besarnya biaya modal ( WACC) pada tahun 2010 WACC sebesar 8,65\%, pada tahun 2011 WACC sebesar 12,65\%, pada tahun 2012 WACC sebesar 14,43\%, pada tahun 2013 WACC sebesar 3,69\%, pada tahun 2014 WACC sebesar 5,36\% dan pada tahun 2015 Wacc sebesar 1,42\%.

Jadi, dapat diketahui bahwa struktur modal optimum pada PT Mustika Ratu Tbk terjadi pada tahun 2015 karena biaya modalnya merupakan biaya modal terendah.

\section{KESIMPULAN}

1. Pada tahun 2010 jumlah hutang jangka panjang sebesar Rp10.638.267.816,-pada tahun 2011 meningkat sebesar Rp 12.000.508.887,- pada tahun 2012 menurun sebesar Rp 10.939.737.916,- pada tahun 2013 kembali menurun sebesar Rp 9.981.975.643,- pada tahun 2014 meningkat sebesar 10.574.595.944,- dan pada tahun 2015 kembali meningkat sebesar Rp 17.165.678.527,-. Kemudian dapat dilihat dari modal sendiri pada tahun 2010 sebesar 248.064.449.550,- pada tahun 2011 meningkat sebesar Rp 268.606.924.389,-- pada tahun 2012 kembali meningkat sebesar Rp 289.604.590.185,pada tahun 2013 menurun sebesar Rp 272.756.376.318,- pada tahun 2014 meningkat 
sebesar Rp 280.128.350.160,- pada tahun 2015 kembali meningkat sebesar Rp 280.857.007.040,-. Dapat dilihat dari gambaran struktur modal dalam pembahasan sebelumnya PT Mustika Ratu Tbk dalam menjalankan aktivitas perusahaan lebih banyak menggunakan modal sendiri dari pada hutang jangka panjang. Pemilihan pendanaan ini menunjukkan bahwa manajemen mengurangi resiko finansial yang akan dihadapi PT Mustika Ratu Tbk dimasa yang akan datang.

2. Biaya modal rata - rata tertimbang (WACC) pada PT Mustika Ratu Tbk dari analisis diperoleh sebagai berikut pada tahun 2010 WACC sebesar 8,65\%, pada tahun 2011 WACC sebesar 12,65\%, pada tahun 2012 WACC sebesar 14,43\%, pada tahun 2013 WACC sebesar 3,69\%, pada tahun 2014 WACC sebesar 5,36\% dan pada tahun 2015 WACC sebesar $1,42 \%$. Dari analisis tersebut terlihat bahwa struktur modal yang diterapkan PT Mustika Ratu Tbk dapat meminimumkan biaya modal rata - rata tertimbangnya pada tahun 2015 terlihat bahwa pada tahun 2015 tersebut adalah biaya modal rata-rata tertimbang paling minimum dari tahun-tahun sebelumnya. Struktur modal pada PT Mustika Ratu Tbk dinyatakan baik karena didukung oleh hasil penelitian yang menunjukkan bahwa biaya modal rata-rata tertimbang atau Weight Average Cost of Capital (WACC) yang meskipun berfluktuasi tetap dapat meminimumkan biaya modalnya. Pernyataan tersebut didukung oleh konsep "struktur modal optimum“ yang menyatakan bahwa perusahaan telah mencapai struktur modal yang optimum jika perusahaan tersebut dapat meminimumkan biaya modal rata-ratanya atau dengan kata lain dapat dikatakan bahwa struktur modal yang mempunyai biaya modal rata - rata tertimbang yang terendah (Riyanto:2001).

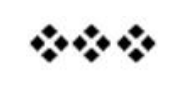

\section{DAFTAR PUSTAKA}

Agus, Sartono. 2011. Manajemen Keuangan (Teori dan Aplikasi). Yogyakarta : BPFE.

Bambang, Riyanto. 2001. Dasar-Dasar Pembelanjaan Perusahaan. Edisi Keempat. Yogyakarta : BPFE.

Brigham, Eugene F dan Joel F. Houston. 2001. Dasar-Dasar Manajemen Keuangan. Buku 1 Edisi 8. Jakarta : Salemba Empat.

Syamsudin, Lukman. 2009. Manajemen Keuangan Perusahaan. Jakarta : Raja Grafindo Persada. 
S, Munawir. 2010. Analisa Laporan Keuangan. Edisi Keempat. Yogyakarta : Liberty.

Suad, Husnan dan Pudjiastuti. 2006. Dasar-Dasar Manajemen Keuangan. Edisi Kelima. Yogyakarta: UPP STIM YKPN.

Sutrisno. 2009. Manajemen Keuangan Teori, Konsep dan Aplikasi. Yogyakarta : Ekonesia. 